Article

\title{
The House that Lars Built. The Architecture of Transgression
}

\author{
Małgorzata Stępnik (iD \\ Faculty of Political Science and Journalism, Maria Curie-Skłodowska University in Lublin, \\ 20-612 Lublin, Poland; malgorzata.stepnik@poczta.umcs.lublin.pl
}

Received: 23 October 2020; Accepted: 2 December 2020; Published: 8 December 2020

\begin{abstract}
This article discusses the motif of the "architecture of transgression", which is present most implicitly, in Lars von Trier's The House that Jack Built. The analysis concerns both the construction of cinematic narrative itself and the subtle allusions, inserted in the script, to two architectural metaphors: the Nietzschean (and Jungian) labyrinth and the Heideggerian die Hütte. Von Trier's film may be read as an oeuvre immersed in literary tradition-from Dante's Divine Comedy to the modern Bildungsroman - as well as inspired by modern philosophy, particularly George Bataille's philosophy of transgression, (as expound in his Erotism and his short 1929 essay on Architecture).
\end{abstract}

Keywords: cinema; architecture; spatial metaphors; transgression; the aestheticisation of crime; Friedrich Nietzsche; Martin Heidegger; Carl Jung; Georges Bataille; Lars von Trier

We are deemed the ultimate evil.

All the icons that have had and always will have an impact on the world are for me an extravagant art. The noble rot.

(an excerpt from Lars von Trier's screenplay of The House that Jack Built, 2018) ${ }^{1}$

Les hommes ne répresentent apparemment dans le processus morphologique, q'une étape intermédiaire entre les singes et les grands édifices.

(Georges Bataille Architecture; Bataille 1929, p. 117)

\section{Introduction: The Hut-The Tower-The Labyrinth}

In 1922, Martin Heidegger moved into a humble hut in Todtnauberg in the Black Forrest (Schwarzwald) - the legendary Hütte, given to him by his wife, Elfriede. In the same year, Carl Gustav Jung, experiencing deep grief after his mother's recent death, decided to buy a plot of land to build a house in Bollingen, on the northern shore of the Obersee. Shortly after, he erected the first part of the whole complex, a massive tower crowned with a pointed roof, which, over time, would be surrounded by several equally massive stone annexes connected by winding passages. That was, as he wrote in his memoirs: "A confession of faith in stone" (Jung [1962] 1989, p. 223).

Eleven years later, the notable Swiss psychiatrist and the creator of analytical psychology, will publish a comprehensive essay entitled: Modern Man in Search of a Soul (N.Y. 1933). At this time also,

1 (Lars von Trier 2018). The House that Jack Built. Directed by Lars von Trier. Zentropa [Denmark], 2018, 153 min. Screenplay: Lars von Trier. Story by: Lars von Trier and Jenle Hallund. Art director: Simone Grau Roney. Producer: Louise Vesth. Director of photography: Manuel Alberto Claro. Music by: Victor Reyes. Starring: Matt Dillon, Bruno Ganz, Uma Thurman, Siobhan Fallon Hogan, Sofie Gråbøl, Riley Keough, Jeremy Davies. This and other quotations are taken from the script. Available online: https://subslikescript.com/movie/The_House_That_Jack_Built-4003440 (accessed on 15 June 2020). 
the "Wiener Journal" will issue a German-language version of his less frequently cited text dedicated to the psychology of a murderer: Blick in die Verbrecherseele (see: Jung [1932] 2014). ${ }^{2}$ In the meantime, Heidegger, as an active member of the NSDAP party, will be elected Rector of the University of Freiburg. The Nazi philosophy professor will soon give a series of lectures titled: On the Essence and Concepts of Nature, History and State, (ten sessions between 3 November and 23 February 1934). In the eighth part of the lecture series, being the most disturbing one, Heidegger introduces the notion of Bodensträndigkeit, that is, "groundedness", being rooted in the soil—an attitude so much desired by the Nazi regime, and at the same time contradictory to the-in his view-dangerous culture of "Semitic nomads" (Heidegger [1933] 2013, p. 56). ${ }^{3}$

In 1933, Sigmund Freud, the father of psychoanalysis-and a symbolic Father figure from Jung's perspective-still continues his Vienesse practice at Berggasse 19 (Could he then ever dream, in his most horrible nightmares, what would happen to European Jews? Could he predict that in several years he would be forced to leave his motherland?). I mention him here because Heidegger's notion of Bodensträndigkeit stands in opposition to Freudian Unheimliche, "the uncanny", even in the etymological sense. ${ }^{4}$ For, as we read in Freud's seminal essay of 1919, the domain of the uncanny includes the category of things that, paradoxically, are both repulsive and attractive, as well as things that seem to be familiar, but in fact remain inscrutable, or even more often, quite the reverse; Unheimlichkeit, a specific "un-at-homeness", or "groundlessness" 5 that is associated with the fear of what remained hidden in the depths, and unexpectedly reveals itself to have been well known to us for a long time. Are we not afraid that, while following the labyrinth paths of our psyche, we will encounter a Minotaur who speaks a well-known language?

I also refer to The Uncanny because the theme of castration anxiety raised in the essay-as akin to the anxiety of being blinded-leads us to associations with Georges Bataille's philosophy of difference and of transgression, which will be discussed later in the text. Additionally, it is worth mentioning here that "the transgressive" intrinsically signifies "transcended of oneself" and slipping into the domain of "the uncanny". It is "transgression", as a key notion in Bataille's heterology (hétérologie), that will serve as a main reference point in my analysis of Lars von Trier's disquieting cinematic oeuvre-The House that Jack Built (2018).

I will "read" the film, so dark yet so intriguing, as-according to Ervin Panofsky's claim expressed in his Studies in Iconology (1939)—symptomatic of our age, with its interests, fascinations and obsessions. Since, as Panofsky writes, from the standpoint of iconology "we deal with the work of art as a symptom of something else which expresses itself in a countless variety of other symptoms, and we interpret its compositional and iconographical features as more particularized evidence of this 'something else'" (Panofsky [1939] 2018, p. 8). ${ }^{6}$

2 The text had been published earlier, in 1932, in London's "Sunday Referee". Here is one of its most interesting passages: "It is a terrible fact that crime seems to creep up on the criminal as something foreign that gradually gains a hold on him so that eventually he has no knowledge from one moment to another of what he is about to do" (Jung [1932] 2014, p. 343).

3 Gregory Fried, in an essay-written for Los Angeles Review of Books-concerning Heidegger's Schwarze Hefte (Black Notebooks), investigates how the philosopher's anti-semitism was intertwined with his concept pf Being. There we read e.g.: "The Jews represent, for Heidegger, a global force that uproots Being from its historical specificity, its belonging to peoples rooted in time and place. As such, Jews are just another representative of Platonic universalism, or liberalism on the grand scale" (Fried 2014). See also: (Fried 2019).

4 "The German word unheimlich is obviously the opposite of heimlich, heimisch, meaning "familiar," "native," "belonging to the home" (Freud [1919] 1959, p. 370).

5 In this context, it is worth mentioning that one of Ronald B. Kitaj's emblematic paintings is entitled The Apotheosis of Groundlessness (1964). I discuss [... ].

6 A scholar (an interpreter), by dint of the "synthetic intuition", is able to read/uncover the "intrinsic meaning of content, constituting the world of "symbolical values"' (Panofsky [1939] 2018, pp. 14, 15). (The expression "symbolical values" was borrowed by Panofsky from Ernst Cassirer). According to Panofsky, iconological interpretation-of the highest degree - needs to be oriented toward the "history of cultural symptoms or 'symbols' in general", and give a suitable "insight into the manner in which, under varying historical conditions, essential tendencies of the human mind were expressed by specific themes and concepts" (Panofsky [1939] 2018, p. 15). 
I propose that von Trier's film can be interpreted as a postmodern work of art, symptomatic of postmodern aesthetics - with its "hybridity", "relativism", "an ironic, sophistical stance", and its special predilection for "pastiche" (Hassan 2003, p. 4; see also Hassan 1985), that is "always and inescapably historical" (Dyer 2007, p. 131). Postmodern, as well, is the strategy of cultural (artistic) appropriation so willingly used by the Danish director. Undoubtedly, "among the theorists of appropriation, it is George Bataille who offers the term perhaps its greatest, and most troubling, cultural extension" (Welchman 2009, p. 195; see: Bataille [1930] 1986b, pp. 91-104).

The postmodern Zeitgeist is reflected in the rhizomatic structure of my essay-rhisomatique in the Deleuzian and Guattarian sense. This kind of structure is thus also suitable in the context of psychoanalytic exegesis, or even say, the psychoanalytic journey abounding with allusions and repetitions. Therefore, in order to present the subject in its complexity, I will use the method of possibly comprehensive hermeneutic journey, drawing from the history of European thought.

It is worth noting that the work by the Danish director fits into a broader context of literary tradition, or better put, the constellation in which there are: the "accursed poets" (from Charles Baudelaire and Arthur Rimbaud to the archetypal poète maudit, François Villon); the rebellious verses of John Milton and the original cosmology of William Blake; the linguistic transgressions of William Wordsworth; Fyodor Dostoyevsky's fascination with crime; as well as, closer to our times, the picaresque confessions of Jean Genet; and the "terrorist" aesthetics by Don deLillo or Kathy Acker, to name but a few.

Nevertheless, I will pay special attention to the motif of architecture-both that imagined in the film and that being itself a cinematic construction - the architecture that is, as Yve-Alain Bois and Rosalind Krauss put it in their analysis on Bataille's oeuvre: "a privileged metaphor of metaphysics" (Bois and Krauss 1997, p. 17) (And indeed—to use Roman Jakobson's distinction-what we are dealing with here is a truly poetic metaphor, not a realistic metonymy.). ${ }^{7}$ Furthermore, I will focus on the motif of wandering, of the road, or better put: roads traversed by von Trier's character, Jack-a kind of iterology designed by the director (and the scriptwriter in one person), that, as we will observe, stems from specific literary and philosophical backgrounds.

It is enough to mention here, that amongst numerous spatial metaphors that could describe the protagonist's journey, one has the special power and resonance: the archetypal labýrinthos. After all, in its structure, a labyrinth resembles the tremendously complex architecture of the human psyche; and navigating its umbrageous corridors may evoke associations with the work of introspection and the toil of gaining self-knowledge (gnothi seauton!), made by a patient during the psychoanalytic process. Besides which, the metaphor of a maze best depicts the spirit and mentality of a modern man, of which Friedrich Nietzsche wrote in The Dawn of Day (Morgenröthe, 1881) (We acknowledge how much classical psychoanalysis owes to him). Here, in one of his aphorisms (no. 169), the philosopher says, commenting on "the Greek genius foreign to us":

“THE GREEK GENIUS FOREIGN TO US.-Oriental or modern, Asiatic or European: compared with the ancient Greeks, everything is characterised by enormity of size and by the revelling in great masses as the expression of the sublime, whilst in Paestum, Pompeii, and

7 Roman Jakobson in his Fundamentals of Language (1956), draws a distinction between metonymy (metonymic function, as characteristic for Realist prose), and metaphor (metaphoric function, as predominant in Romantic and Symbolic poetry). (It is based on another distinction: the principle of contiguity versus the principle of similarity). Jakobson applies this division to the sphere of visual arts, in which, as he writes "metonymical orientation of cubism, where the object is transformed into a set of synecdoches" gives place to "patently metaphorical attitude" of Surrealist painters (Jakobson [1956] 2002, p. 92).

In the context of this article's topic, it is worth mentioning that a Polish scholar, Mieczysław Porebski-referring to Jakobson's thought-draws a similar dichotomy between metonymies and metaphors present in the "language" of architecture. In his view, for example, "a paleolithic cave", as a symbol of a "Mother's womb" (uterus), may also be read as "the underground kingdom of metonymy" ("podziemne królestwo metonimii"); for rituals celebrated within a cave are always "rites of participation". Whereas, a Sumerian Ziggurat may serve as an example of an architectural metaphor-"a metaphor piling up into the sky" ("spiętrzająca sie w niebo metafora"). According to Porebski, that is because the tower-the Tower of Babel narrative is especially significant here-is not conducive to communication, but rather to "a separating ritual of transfiguration" ("rytuał transfiguracji"). See: (Porębski 1972, pp. 164-65). 
Athens we are astonished, when contemplating Greek architecture, to see with what small masses the Greeks were able to express the sublime, and how they loved to express it thus. In the same way, how simple were the Greeks in the idea which they formed of themselves! How far we surpass them in the knowledge of man! Again, how full of labyrinths would our souls and our conceptions of our souls appear in comparison with theirs! If we had to venture upon an architecture after the style of our own souls-(we are too cowardly for that!) - a labyrinth would have to be our model. That music which is peculiar to us, and which really expresses us, lets this be clearly seen! (for in music men let themselves go, because they think there is no one who can see them hiding behind their music)." (Nietzsche 1911, p. 149) ${ }^{8}$

The journey through the Nietzschean maze is associated with the spirit of music, and hence also with the Dionysian transgressiveness. I allude to the famous study Die Geburt der Tragödie aus dem Geiste der Musik (The Birth of Tragedy Out of the Spirit of Music), published in 1872, where Nietzsche introduces a distinction between the Apollonian and the Dionysian-in other words, between the glory of passivity (contemplation) and the glory of activity (intoxication). Thus, on the one hand, we have a dream-like world, immersed in harmony and brightness - " the fully wise calm of the god of images" (Nietzsche [1872] 2009, p. 12), while on the other, we have the domain of musical ecstasy and transgression, the "piercing scream" of generations (ibid., p. 20), "the exuberant fecundity of the world will" (ibid., p. 58).

Here the will to transgress, to reach the "tragic insight" (ibid., p. 54) that replaces logical reasoning - is one of the most crucial motives of the modern and perhaps even more: postmodern artistic and literary production. A labyrinth, as Denis Hollier writes in his study Against Architecture, commenting on Bataille's works, "claims to be the official park of the Uncanny". Though, the question remains: "What would a labyrinth be without a minotaur: a labyrinth without blood?" (Hollier [1974] 1989, p. xi).

Now, let me come back for a moment to Heidegger's modest Hütte and Jung's tower house built over the course of years, created as "a work in progress". The way to the former is Holzwege, wood-ways "off the beaten track". The latter is, in a sense, a way itself, written in stone. It serves as a visual symbol of the process of individuation, of achieving the integral fullness of one's being. ${ }^{9}$ Hegel, in his thesis on Architecture, defined the house as "a fundamental type" (Hegel [1835] 1975, p. 661). The frigid algebra of the classical architecture that takes its origin in the form of antique homestead, "devices the substance of its plan and figuration in the light of spiritual purposes, while its shape is the product of human intellect and has no direct model" (ibid., p. 662). In turn, Marc-Antoine Laugier in his Essai sur l'architecture (1753) — repeating the Vitruvian myth of the origin of architecture ${ }^{10}$ —pointed out that the perfect form of an ancient Greek (and Roman) building-undisturbed by later accretions or "defects"-derives from la petite cabane rustique (Laugier 1753, pp. 12, 13), "the little rustic cabin".

8 The similar metaphor appears in the aphorism no. 230: “'UTALITARIAN'-At the present time men's sentiments on moral things run in such labyrinthic paths that, while we demonstrate morality to one man by virtue of its utility, we refute it to another on account of this utility" (Nietzsche 1911, p. 198).The topos of the labyrinth is also present, among others, in Nietzsche's poetry, namely: his Klage der Ariadne (Lament of Ariadne), inserted in his Dio-nysos-Dithyramben, written in 1888 and first published in 1891.

9 "Individuation means becoming an 'in-dividual', and, in so far as 'individuality' embraces our innermost, last, and incomparable uniqueness, it also implies becoming one's own self. We could therefore translate individuation as 'coming to selfhood' or 'self-realization" (Jung [1916] 1967, p. 173).

The self-as Jung explains elsewhere-is far wider than what is enclosed in one's "conscious personality" (ego): "Clearly, then, the personality as a total phenomenon does not coincide with the ego, that is with the conscious personality, but forms an entity that has to be distinguished from the ego ( ... ). I have suggested calling the total personality which, though present, cannot be fully known, the self. The ego is, by definition, subordinate to the self and is related to it like a part to the whole" (Jung [1951] 1997, p. 289).

10 In the second chapter of De architectura, entitled: The Origin of the Dwelling House, Vitruvius writes: "Therefore it was the discovery of fire that originally gave rise to the coming together of men, to the deliberative assembly, and to social intercourse. So, as they kept coming together in greater numbers into one place, finding themselves naturally gifted beyond the other animals in not being obliged to walk with faces to the ground, but upright and gazing upon the splendour of the starry firmament ( . . ) , they began in that first assembly to construct shelters" (Pollio [1465, 30-20 BC] 1914). 
According to Abbé Laugier, that simplest, rudimentary, one might say archetypal form, consisting only of round columns, entablatures and pediment, had been the result of a humble observation of nature and "the imitation of her proceedings" (Laugier 1755, p. 11). ${ }^{11}$

It can therefore be assumed that the "vernacular" and "natural" simplicity of Heidegger's hut contradicts the Jungian sophistication and mystery. Additionally, analogically: Bodensträndigkeit contradicts Unheimlichkeit, the regularity of construction contrasts with its irregularity, the specific "certainty" of "spiritual purposes" with the incomprehensibility (of a human psyche), the objectivised vision with the subjective story (Jung's "innermost thoughts"12), the "totality" (Figure 1$)^{13}$ with the "wholeness" understood as "a familial wholeness in which all sorts of domestic animals likewise participate" (Jung [1962] 1989, p. 224), and, last but not least-the terror of (natural) order with the specifically human error (Errare humanum est... ), with the symbolic journey towards illumination.

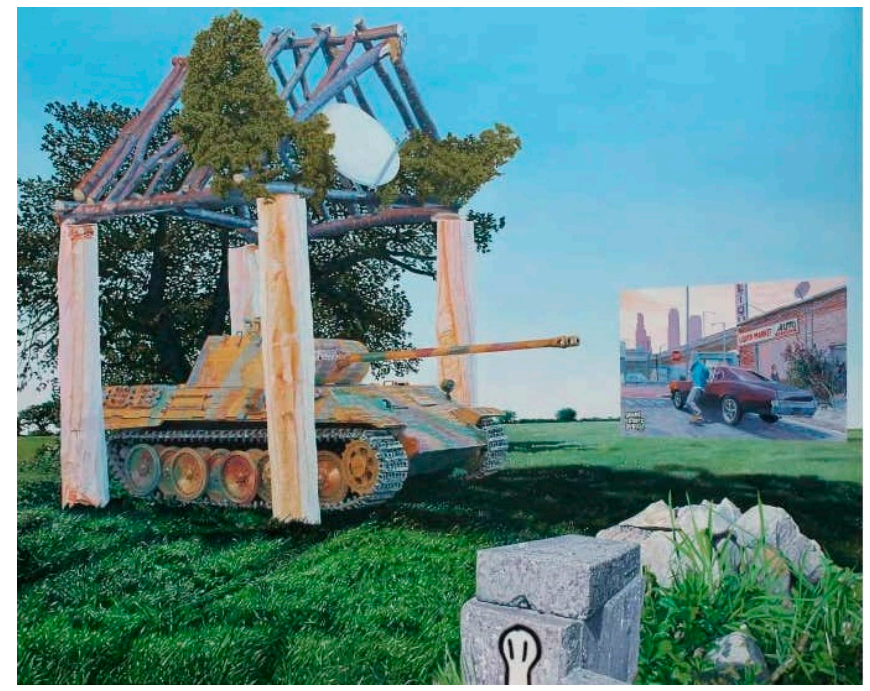

Figure 1. Paul Collinson, Heidegger's Hut, 2015, oil on canvas, 120/150 cm. Courtesy of the artist.

11 "The man is willing to make himself an abode which covers but not buries him. Some branches broken down in the forest are the proper materials for his design. He chuses four of the strongest, which he raises perpendicularly and which he disposes into a square. Above he puts four others across, and upon these he raises some that incline from both sides. This kind of roof is covered with leaves put together, so that neither the sun nor the rain can penetrate therein; and now the man is lodged. ( ... ) Such is the step of simple nature: It is to the imitation of her proceedings, to which art owes its birth. The little rustic cabin that I have juft described, is the model upon which all the magnificences of architecture have been imagined, it is in coming near in the execution of the simplicity of this first model, that we avoid all essential defects, that we lay hold on true perfection. Pieces of wood raised perpendicularly, give us the idea of columns. The horizontal pieces that are laid upon them, afford us the idea of entablatures. In fine the inclining pieces which form the roof give us the Idea of the pediment" (Laugier 1755, pp. 10-12). Laugier on Greek/Roman architecture: "Architecture owes all that is perfect in it to the Greeks, a free nation, to which it was reserved not to be ignorant of anything in the arts and sciences. The Romans, worthy of admiring, and capable of copying the most excellent models that the Greeks helped them to, were desirous thereto to join their own, and did no less than shew the whole universe, that when perfection is arrived at, there only remains to imitate or decay" (ibid., pp. 3-4). Laugier refers to Maison Carrée in Nîmes as such the perfect example, and in the same place he writes: "Do not let us lose sight of our little rustic cabin. I can see nothing therein, but columns, a floor or entablature; a pointed roof whose two extremities each of them forms what we call a pediment. As yet there is no arch, still less of an arcade, no pedestal, no attique, no door, even nor window. I conclude then with saying, in all the order of architecture, there is only the column, the entablature, and the pediment that can essentially enter into this composition. If each of these three parts are found placed in the situation and with the form which is necessary for it, there will be nothing to add; for the work is perfectly done" (ibid., p. 13).

12 Jung in his memoirs writes: "I had to achieve a kind of representation in stone of my innermost thoughts and of knowledge I had acquired" (Jung [1962] 1989, p. 223).

13 As Paul Collinson—an eminent English painter and intellectual—writes in his essay accompanying his painting entitled Heidegger's Hut: "The Classical is the default of the megalomaniac and totalitarian" (Collinson 2019, p. 4). See also e.g. an interesting study by Adam Sharr: (Sharr 2006). It is worth noting that in this painting Collinson quotes the form of a "hut" as imagined by Charles-Dominique-Joseph Eisen. Eisen's engraving served as a frontispiece to the second edition of Laugier's Essay on Architecture. 
So, what is the house that Jack built like? It needs to be separated clearly: what is the house that Lars built like?

\section{Jack's Iterology}

This is the melancholy Dane

That built all the houses that lived in the lane

Across from the house that Jack built.

(Jack Spicer, The House that Jack Built, an excerpt from the poem; Spicer 1998, p. v)

The eponymous "Jack" in von Trier's last oeuvre-portrayed through captivatingly reserved acting by Matt Dillon-is an engineer by profession, an unfulfilled architect and a psychopathic serial killer, and, strikingly, is to be found to be suffering from obsessive-compulsive disorder. (To my knowledge, OCD may be related to neuroticism rather than psychopathy or sociopathy. Anyway, licentia poetica ... ). He confesses his crimes, committed over a span of twelve years-how perverse these confessions are-to a character whom he calls "Verge". Obviously, that name is a most clear literary allusion, a familiar diminutive of "Vergil"; and thus, it alludes to the greatest of Roman epic poets, whom Dante Alighieri made his guide in La Divina Commedia (1320). Let me add here that, casting that role with Bruno Ganz-an outstanding Swiss actor who passed away recently, and whose brilliant roles range from an Angel figure to Hitler-was a directing ploy that deserves the highest praise.

Even the main poster accompanying the film (Figure 2)-there are several, which I will mention later-suggests that the narrative structure of von Trier's oeuvre will be related to the composition of Dante's Divine Comedy. The design is based on a wide-angle photograph depicting a specific "living image" (tableau vivant), quite faithfully, yet not too pedantically, imitating the layout of the magnificent, epic canvas by Eugène Delacroix-The Barque of Dante (La Barque de Dante, 1822, Louvre collection (Figure 3) (In a profound way, Delacroix took inspiration from The Raft of Medusa, which was painted a few years earlier by his friend Théodore Gericault). In the photograph, similarly to the pictorial original, we recognise the boatman Phlegyas, his back turned to us, fighting with wind and rough, foamy waves. In the middle, we see Verge-Vergil, the guide through the eighth circle of Inferno, in a way, also a psychopomp figure, and quite significantly, wearing a late 19th century frock coat. Finally, on our left, we see Jack-Dante, shrouded in a red mantle.

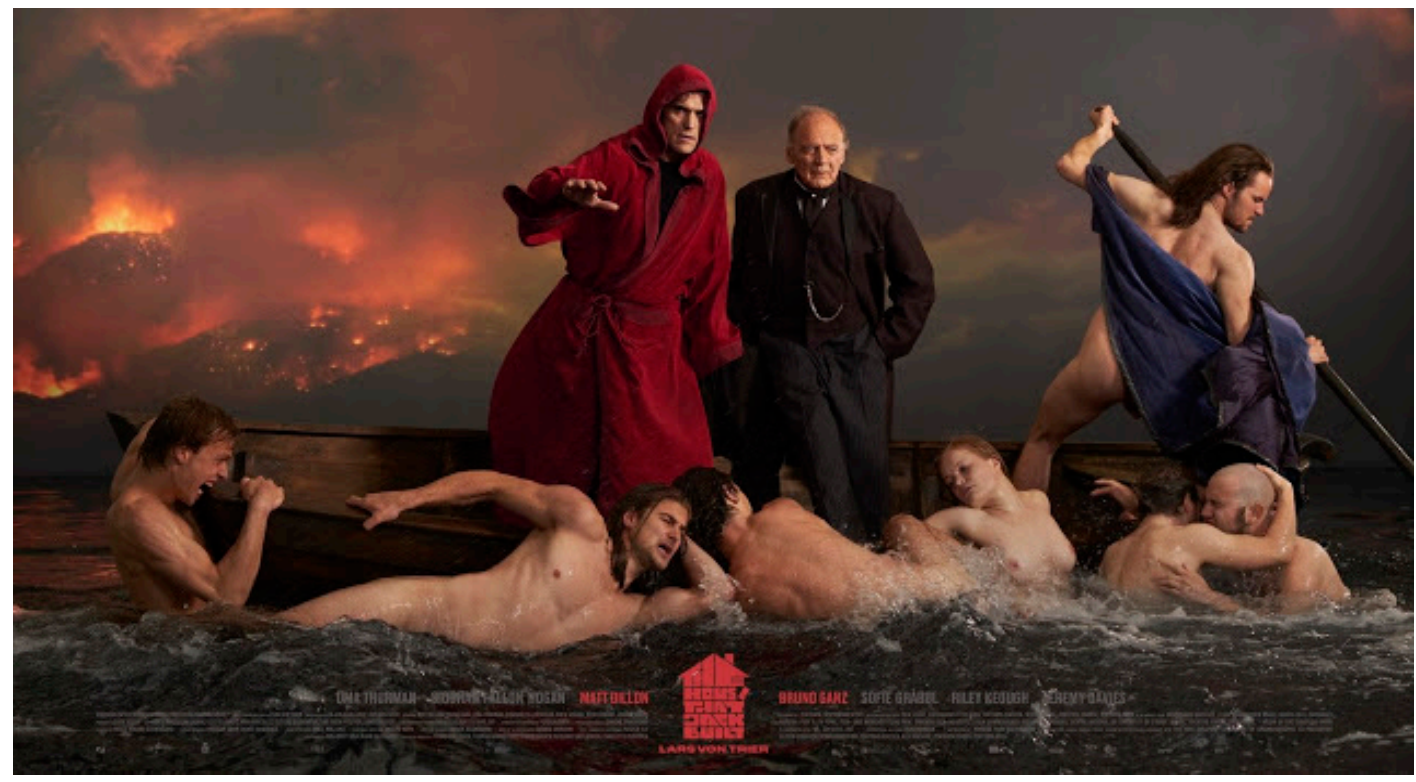

Figure 2. The Einstein Couple (Maria Einstein-Biilmann and Philip Einstein-Lipski), a poster for Lars von Trier's The House that Jack Built, 2018. Courtesy of Zentropa and The Einstein Couple. 


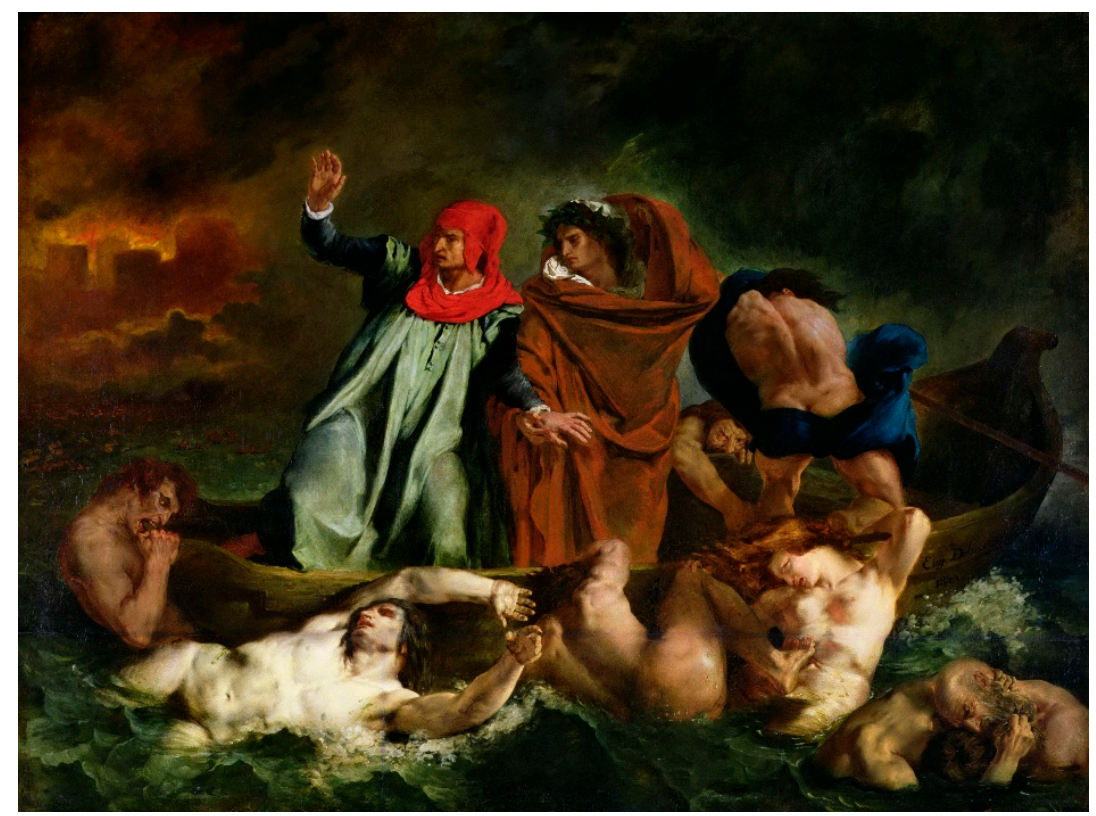

Figure 3. Eugène Delacroix, La barque de Dante (The Barque of Dante) or: Dante et Virgile aux enfers (Dante and Virgil in Hell), 1822, oil on canvas, 74.4" $(189 \mathrm{~cm}) / 94.8^{\prime \prime}(241 \mathrm{~cm})$, Louvre Museum, Paris. Wikimedia commons/Public domain.

The same scarlet mantle-although absent in Delacroix's painting, but accordant with the traditional iconography of Dante ${ }^{14}$ —is donned by Dillon throughout the film, which, I think, makes something more than an elegant colouristic counterpoint to a slightly greyish background of the American province of the 1970s. So, we have the wanderer in scarlet-a colour of ambiguous symbolism: monarchic, martyred, and in antiquity "reserved" for prostitutes-who leads the spectator into the darkest corners of his psyche. Jack as Dante, the murderer as the poet-such a surprising, yet outrageous juxtaposition is informative in regard to the main (yet only implicit) theme of this cinematic story, that is-the theme of crime as art, or, in other words: the aestheticisation of crime.

"I will tentatively divide my tale into five randomly chosen incidents" - Jack declares at the outset of his confessions. However, they seem not to be chosen randomly at all. These euphemistically labelled "incidents" are, in fact, unbelievably cruel murders, determining the trajectory of the protagonist's mad procession. (The Greek word komos, an etymological root for "comedy" — divine or profane—literally means "procession"). Indeed, there is something in Jack's journey that makes us think of a transgressive, Dionysian procession, intoxicated-Jack calling himself Mr. Sophistication is, in fact, intoxicated with his false refinement—but, at the same time, based on its own logic and linear order. The script, explicitly inspired by Dante's Inferno, is also a more universal story about passing through circles of initiation, about a symbolic rite de passage. "Where does that path lead"—asks the murderer? "On the other side. It leads out of hell and up"-replies Verge (Let me note that the noun "verge" is synonymical to "an edge" or "a border").

Regarding the triple structure of the ritual process, as conceptualised by Victor Turner-"separation", "liminal period" and "reaggregation"-Jack seems to remain at the middle stage, that is, of liminality, in which "characteristics of the ritual subject (the 'passenger') are ambiguous" (Turner [1969] 1991, p. 94). In a way, therefore, he experiences a state of an awkward "formlessness" - here again, Bataille's l'informe turns out to have a special connotation.

14 In painterly tradition, Dante is usually depicted in a red, hooded mantle. That is how he was depicted by, among others: Domenico di Michelino, Sandro Botticelli, William Blake, Jean-Léon Gérôme, William-Adolphe Bouguereau, Gustave Doré, Ilya Repin, or Hans Makart. 
The classical composition of von Trier's film is crowned by an epilogue, in which the above described scene, "frozen" in the photograph, comes alive. That part has been titled by the director as Katabasis, which is a term that originates from Greek mythology and describes a hero's descent into the world of the dead. However, in a symbolic way, the motif of katabasis may also be associated with the descent into the labyrinth of one's subconscious, with an underground journey, at the end of which one is confronted with dark promptings of his/her Es (Freud), or Shadow (Jung).

Such an interpretation is actually implied in the film's title, which may not be instantly obvious. The phrase: "the house that Jack built" derives from an old-English children's song, one of the so-called nursery rhymes that not only served entertainment purposes, but conveyed moral instruction. (The above-cited poem by Jack Spicer is not the only contemporary variation on the old-English original). ${ }^{15}$ What is particularly significant is that the song bears the characteristics of a "cumulative tale", ${ }^{16}$ that is, a tale in which events gradually build up and get complicated around a certain theme repeated in a refrain (it is their repetitive character that directs us back to psychoanalysis, namely-to the Freudian "repetition compulsion" and childish regression). As stated by James Orchard Halliwell, in his classic 1849 work, "Accumulative tales are of very high antiquity. The original of "The House that Jack Built' is well known to be an old Hebrew hymn in Sepher Haggadah. It is also found in Danish, but in somewhat shorter form ( ... "). As he specifies, the title of the Danish version is: Der har $d u$ det Huus, som Jacob bygde (Halliwell 1849, p. 6). Is it possible then, that von Trier learned the song in

15 See e.g.,: “My body my temple//This temple it tells/'Step intoo the house that Jack built"”. (Metallica, Load album, 1996, lyrics: James Hetfield).

16 According to a dictionary entry: "Cumulative rhymes, also known as cumulative verses, and cumulative tales are closely related forms of storytelling. Cumulative rhymes add a line or two with each new verse, after repeating the information presented in the earlier verses. As a result, each new verse is longer than the previous one. The subject of a cummulative rhyme may be serious and created for adults, as in some Hebrew chants, or silly and aimed at both adults and children.

Cumulative tales are simple stories with repetitive phases. The tales unwind and then rewind and repeat, with new elements added with each repetition. The rhythmic structure of these tales is very appealing, especially for children." Entry; "Cumulative Rhymes and Tales" (Sherman 2015, p. 104).

James Orchard Halliwell, in his classic anthology of 1842, quotes the whole text of "The House that Jack Built" tale. Here, after Halliwell, I am giving the first and last passages of the rhyme:

"1. This is the house that Jack built.

2. This is the malt,

That lay in the house that Jack built.

3. This is the rat,

That ate the malt,

That lay in the house that Jack built.

4. This is the cat

That kill'd the rat

That ate the malt

That lay in the house that Jack built."

[... ]

11. This is the farmer sowing his corn,

That kept the cock that crow'd in the morn,

That wake'd the priest all shaven and shorn,

That married the man all tattered and torn,

That kissed the maiden all forlorn,

That milk'd the cow within the crumpled horn,

That tossed the dog,

That worried the cat,

That killed the rat,

That ate the malt,

That lay in the house that Jack built."

See: (Halliwell 1842, pp. 161-63). 
his mother tongue? Leaving this question open, I shall let myself focus for a moment on the oldest, so to speak, archetypal version mentioned by Halliwell, that originates from Jewish tradition.

The song entitled Chad Gadya (One Little Goat) represents the chain of beings, beginning from the eponymous animal (a legible symbol of sacrifice), who is eaten by a cat, who is bitten by a dog, et cetera. In the end, good God appears to destroy the Angel of Death. The above-mentioned English version, almost identical in its structure, yet with other "actors", ends with the image of "the farmer sowing his corn". Both figures: Almighty God and the Farmer, symbolise the victory of good in the world only seemingly ruled by evil. (In which an animal kills an animal, and a human kills a human.) The parable seems to say that before the final divine intervention occurs, and the farmer's effort brings a new crop (life), we need to accept that in the great order of existence, there is a place both for an innocent lamb (a prefiguration of the Redeemer), and for a predator as beautiful as a tiger.

I deliberately allude to magnificent poems by William Blake, included in his Songs of Innocence and of Experience (1789): The Lamb and The Tyger. For, it is significant that the Blakean oeuvre appears among quite a few cultural references in von Trier's film. (Note that the English poet and artist created a series of illustrations to Dante's Divine Comedy). Here is a fragment of the conversation between the murderer and his guide:

Jack: "God created both the lamb and the tiger. The lamb represents innocence, and the tiger represents savagery. Both are perfect and necessary. The tiger lives on blood ( ... ) and that is also the artist's nature."

Verge: "You read Blake like the devil reads the Bible. After all, the poor lamb didn't ask to die in order to become even the greatest art."

Truly, such a reading of Blakean philosophy would be intellectual (and ethical) abuse, given that the poet seems to associate his tiger's "fearful symmetry" with the severity and inexorableness of justice, which, like nature, knows no mercy. (In this respect, he echoes the thesis of "merciless Nature" put forward by 15th century theologian, Thomas à Kempis; see: à Kempis [ca. 1400] 1998, pp. 90-92). It is also the "fearful symmetry" of Reason and of rational cognition, by Blake equated with the (satanic) "architect", Urizen.

The issue of Jack's—and indirectly, von Trier's—attitude towards Nature and Reason will be discussed later in the text. At this point however, I would like to mention another possible meaning of cumulative tales. That is to say, that the structure of such parabolic stories, crowned with the expected salvation, resembles, at least in a way, the psychoanalytic process, through which the analysand-struggling with "demons" of melancholy, neurosis or morbid obsessions-performs an act of self-recognition, as well as soothing self-purification (that is: catharsis).

The theme of inner struggle (psychomachy) and inner journey is present in several of von Trier's works (That struggle, though, is not always victorious). In Antichrist (2009)—probably the most provocative of his productions-the protagonist, who is, by the way, a psychotherapist, seeks escape from his wife's murderous madness in the midst of a forest. From the standpoint of the Jungian theory of archetypes, it can be stated that he strives to escape his Shadow (but to no avail), being a complementary part of his psyche, that is: Anima (In this case, her power is devastating). It is striking to what extent Antichrist may have been inspired in its structure by Ingmar Bergman's Hour of the Wolf (1968). In Vargtimmen, however, a destructive madness is not a female, but a male curse.

In my view, The House that Jack Built may be regarded as postmodern, if only for the reason of an almost overwhelming accumulation of cultural references, some kind of eclecticism, and, as we will see later on, its having been inspired by poststructuralism and the philosophy of difference. In this sense, von Trier's declaration that it is "maybe the most traditional film" that he has ever made, appears to be pertinent afterwards: (Gilbey 2017). What is more, that rich "patchwork" may also be read as a cinematographic version of Bildungsroman, for the drastic adventures of Jack-who considers himself an artist—are, as I have already mentioned, arranged in a specific order. The succeeding crimes, blithely named by him as "incidents", designate—in a metaphorical sense-the stages of constructing 
the "creative" persona. Thus, Jack may be regarded as the processual personality; and the beginning of that process is marked with a symbolic object.

In the film's fable, Jack/jack is a twofold actor (or agens): a person and a tool; (which is a good ploy indeed). The broken "jack" in the hands of the first victim (in this role Uma Thurman), works like Chekhov's gun, announcing and causing the dark series of more and more drastic murders. The very moment in which Jack becomes aware of his own nature, his fate and life's purpose, may be compared to the moment of the first illumination or, at least, intuition of the one who suddenly recognises the creative aspect of his being. (Statements like: "I always knew I was an artist" are usually false, unless we are dealing with a genius). So, in a way, an opportunity makes ... "an artist".

The second and the third victims—-still not deliberately chosen, but accidental—inspire Jack "the artist" to take up increasingly complex actions, to attempt to create his first compositions. Their perversely "aleatoric" dimension is actually explicitly expressed in these words: "It turned out that the little old lady who was merely an accident added a great touch of humour to my stayed photographs". At the same time, here appears the motif of tableau vivant, composed of dead bodies-the most terrifying and difficult, or rather impossible to be erased from memory-a kind of a visual aporia. Let me add that the tableau vivant motif is quite familiar in the tradition of transgressive literature: it is enough to mention the living pictures imagined by a fictional painter, Frédéric Tonnerre in Pierre Klossowsky's scandalising surreal trilogy published in 1965 under the title Les Lois de l'hospitalité (Laws of Hospitalty). In the context of the discussed film, Scott Durham's argument that tableaux vivants primarily serve as visual models of "the unactualised utopian desire" (Durham 1998, p. 76), sound especially significant.

In the following sequences of the film, Jack, more and more absorbed by his "utopian desire", makes his "compositions" more intricate and more brutal. He uses dead human bodies as "material" to what he blasphemously calls his "art"; which evokes associations with the darkest of nazism's and colonialism's sins. The Einstein Couple (Maria Einstein-Biilmann and Philip Einstein-Lipski) who authored a series of posters for the film - seven of which depict the actors and the director in impossibly twisted poses-on their social media profile, give such an explanation: "Inspired by Jack's sophisticated, psychopathic mind, we have portrayed the characters as sculptural building blocks in his eternal pursuit of perfection" (Figure 4, The Einstein Couple 2018). In a way, it brings to mind the long and quasi-philosophical titles of Damien Hirst's works; (e.g., The Physical Impossibility of Death in the Mind of Someone Living of 1991). Hirst's dead sharks or cows immersed in formaldehyde solution, as well as Maurizio Cattelan's taxidermied horses have entered the canon of contemporary art; the canon predominantly governed by capricious tastes of the rich collectors.

Are those works more terrifying than von Trier's last production? Certainly not in the graphic content. The horror lies rather in the fact that animals were killed to serve as artistic "artifacts". What is more, we need to remember that in cinematic fiction, even the darkest images do not entail real victims. ${ }^{17}$ However, this is only one side of a coin. The question of the moral significance of von Trier's film—of its very ethical core-remains at least partly open.

At the end of his "creative" journey, having gone through all the stages of his Bildung, Jack decides to perform the "total" work of art, a kind of Gesamtkunstwerk. (In a way, it is Verge who provokes him by saying these words: "Think, Jack, after all you are an engineer and call yourself an architect.") Thus, a perverse installation is created-the three-dimensional "house" made of victims' dead bodies, the horrifying hut. On one side, it is unnatural —after all, art is the domain of artificiality—and even unthinkable by the sane mind. On the other side, however, it is natural in its form, that reproduces the simplicity and "functionality" of the vernacular dwelling. Jack is Nature's "actor", a predator from the darkest part of the natural world. "Your house is a fine little house, Jack. It's absolutely usable" —says

17 A certain scene featuring an animal raised controversy among the viewers. The case was, though, examined by PETA (People for Ethical Treatment of Animals). On 17th of May 2018 PETA issued a statement, in which they said that the disturbing scene was "created using movie magic" (Telegraph Reporters 2018). 
Verge with bitter irony. Here is the deepest horror, the "heart of darkness": the usable architecture of death.

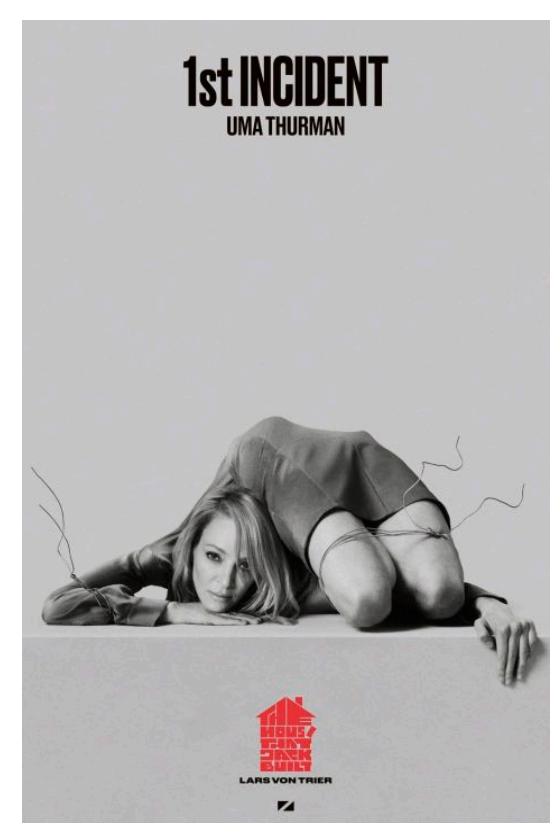

Figure 4. The Einstein Couple, a poster for Lars von Trier's The House that Jack Built, 2018, (featuring Uma Thurman). Courtesy of Zentropa and The Einstein Couple.

\section{The Aestheticisation of Crime and the Sacred Transgression}

May an image of the evil be an apotheosis of the evil? Perhaps it is possible: however, I am far from saying that it applies in that case. Should we take von Trier's words literally when, during the Cannes press conference following the screening of Melancholia (2011), he declares: "OK, I am a Nazi"? Similar indignation—quite rightly, I think—was provoked by an eminent avant-garde composer, Karlheinz Stockhausen, at a Hamburg press conference on the 16th of September 2001 (Albeit, the indignation might have been somewhat calculated by the artist). Having been asked about his reaction to the terrorist attack on the World Trade Center, he replied that he regarded it as "the greatest work of art that is possible in the whole cosmos", and as "something in one act" that "we couldn't even dream of in music" (see: Lentricchia and McAuliffe 2003, p. 6). Von Trier remained "persona non grata" at the Cannes Film Festival for several years, whereas the ostracism Stockhausen encountered caused him to withdraw gradually from public life.

His unfortunate speech brings to mind that of Maria Linde, a fictional character from Jacek Borcuch's Sweet End of the Day (Stodki koniec dnia/Dolce Fine Giornata, 2019). ${ }^{18}$ Maria, a Nobel Prize winner in poetry, a Polish Jew for years living with her family in the Tuscan Volterra, while giving an occasional speech perplexed her audience, experiencing shock from the recent terrorist attack in Rome's Campo di Fiori-a symbolic place indeed-by equating that criminal act with "a work of art". In this case, again, a small architecture is at play. For, in Borcuch's film it is a cage, set on the main square of the town, that serves as a highly significant metaphor. It is an allusion-explicitly expressed in the film - to Ezra Pound, who, in May 1945 was arrested, and then transferred to a detention camp in Pisa, where he spent three weeks kept in a steel cage—punishment for his earlier intellectual "romance" with fascism. (And here, Dante's poetry appears like a refrain, as Pound's Cantos was supposed to be a modern version of the Divine Comedy).

18 The screenplay was authored by Jacek Borcuch and Szczepan Twardoch. Krystyna Janda was awarded at 2019 Sundance Film Festival for the role of Maria Linde. 
Stockhausen later tried to explicate his outrageous "performance". (The motives of the fictitious Maria Linde are left to be guessed by the viewer). In a statement published on his website, the composer clearly referred to the attack on the World Trade Center as "criminal act", whilst at the same time emphasising its "spiritual" consequences: "But what happened spiritually, this jump out of security, out of the self-evident, out of everyday life, this also happens in art ... or it is worthless" (see: Lentricchia and McAuliffe 2003, p. 10). As Frank Lentricchia and Jody McAuliffe write in their book entitled Crimes of Art and Terror, "a touch of envy-envy of terrorism-appears to creep in" such a self-exegesis (ibid., p. 7). It is, as a matter of fact, a jealousy of the ability to create a powerful and a sustainable effect-a perfect form. Yet, from an ethical standpoint Stockhausen's claim is still suspect, as he speaks of "the events themselves, not their artful representation" (ibid., p. 8).

Indeed, the aestheticisation of crime is morally acceptable only as an "artful representation" or "artful imagination" (Not as an act itself). ${ }^{19}$ In artistic fiction-let me once more quote the German composer-"this jump out of security, out of the self-evident" is something desirable by all accounts. Such an idea may be found, for example, in Russian Formalists. Pivotal here is the notion of "defamiliarisation" (obstraneniye) proposed by Victor Shklovsky in his seminal essay on Art as Technique (1917). The defamiliarisation, in other words: the "making strange", is a factor that fractures our everyday perception, that over time becomes more and more habitual and automatic, (as the work of perception is more about eliminating that memorising data). Obstraneniye forms a counterpoise to the natural "habitualisation" and "algebraisation" of language (Shklovsky [1917] 1965, p. 12). As Shklovsky further writes:

"The technique of art is to make objects 'unfamiliar', to make forms difficult, to increase the difficulty and lengh of perception because the process of perception is an aesthetic end in itself and must be prolonged. Art is a way of experiencing the artfulness of an object, the object is not important". (Shklovsky [1917] 1965, p. 12)

The literary (and cinematic) technique of defamiliarisation, used to evoke the desired "difficulty", may, for example, lie in employing a surprising narrator. In this context, Shklovsky points to Leo Tolstoy's Kholstomer, a story narrated by a horse (Shklovsky [1917] 1965, p. 13) (it is a splendid text, indeed, not only because of that daring strategy). We can also assume that defamiliarisation happens to be caused by the aesthetics of the abject, by turpistic images painfully cutting into our memory and consciousness. The artistic bizarreness is inevitably connected with the transgression, otherness, being in a state of liminality, and, last but not least, with the domain of the uncanny.

A vivid echo of Shklovsky's concept is found in Brechtian thought. The famous playwright and theatre reformer introduced the notion of Verfremdungseffekt, that is: "distancing effect" or "alienation effect", which is very similar to the above described "defamiliarisation" (obstraneniye) (see: Bertolt Brecht's essay on Alienation Effect in Chinese Acting, 1936). The sense of Verfremdungseffekt can be summarised as follows: it is about evoking in the viewer - by various means-the feeling of deepened distance towards the characters on stage; and thereby reducing the viewer's natural tendency to identify with dramatis personae. It is also about evoking a shock that results in the revision of one's beliefs and thinking habits (Can we really identify with a serial killer?). It is probably just a coincidence that the Brechtian phrase: "You want me to show you the way to the next whisky bar?"- -being a quotation from Alabama Song, written by Brecht in 1927 and soon after completed with the catchy music by Kurt Weil-appears twice in von Trier's script. However, even if it is just a coincidence, what an intriguing one.

19 Therefore, I cannot fully accept the analogy drawn by Cynthia Ozick in her article entitled Dostoyevsky's Unabomber, namely-the label of "a philosophical murderer" she gives both to Crime and Punishment's protagonist and a real killer-Ted Kaczynski. As she writes: "Both are élitists. Both are idealists. Both are murderers". In my view, concerning Kaczynski-whose bombs killed several people—only the last expression is true (Ozick 1997). 
While we are speaking about the soundtrack of The House that Jack Built, it is worth noting that, apart from the original score composed by Victor Reyes and the above-mentioned song by Brech/Weil duo, the film also features a short video fragment of Glenn Gould's beautiful concert interpretation of Johann Sebastian Bach's Partita No. 2. This musical citation-invoked each time Jack reflects on beauty and on the meaning of "icons" — may be read as emblematic for a "high-brow taste". The fact of participating in such a refined music culture seems to Jack an emblem of his own (false) refinement. (Not infrequently, the cinematic criminals have the highest tastes). Mr. Sophisticated, however, is merely a recipient, not an artist, merely an engineer, not an architect. "An engineer reads music, an architect plays music" — as is stated in the script, even though something like "the art of hearing" exists, as proposed by Nietzsche in Ecce Homo (Nietzsche [1908] 2005, p. 123).

The soundtrack also includes the hit song composed by Percy Mayfield, and sung by Ray Charles-despite numerous covers, it is Charles's performance that remains the best ever-that is, Hit the Road Jack, and obviously_-"don't you come back no more!". This phrase sounds like a conviction. And verily, Jack the psychopath vanishes in the deepest circle of Inferno. However, is it the judgement from the divine Judge, from Nature, or perhaps from ourselves, so outraged, but so willingly following Jack's uncanny paths?

Or, maybe von Trier leaves the final interpretation to the viewer's own imagination and sensitivity: the linear trajectory of Jack's road to hell versus the looped paths of the Nietzschean labyrinth; the crime and its punishment versus the determination of eternal return. As a matter of fact, the structural composition of that "comedy" is marked with recurrence and repetition. Large parts of the script, repeated at the beginning and at the end, serve as narrative brackets within which the whole story unfolds. The thread of determinism and a certain predictability is apparent in these of Verge's returning lines: "People are overcome with a strange and sudden need to confess on these trips (... ), but do carry on merrily. Just don't believe you're going to tell me something I haven't heard before".

There is something in it of the Nietzschean ewig wechselnd, that is "the eternal alteration", being "the highest possible formula of affirmation" (Nietzsche [1908] 2005, p. 123). The ewig wechselnd, as the philosopher himself confessed, was the core concept of probably his most significant work: Thus Spoke Zarathustra (Also Sprach Zarathustra, 1883). "The new gravity: the eternal recurrection of the same. The infinite importance of our knowing, erring, of our habits, ways of living for all that is to come" - he noted in his diary in August 1881, still enthralled with the feeling of illumination he had experienced a while before, during his walk in the woods towards Silvaplana, near Surlej (see: Parkes 2005, p. xxii). That sensation-belonging to the category of "the sublime" — had been prompted by the view of "a huge pyramidal boulder" (Nietzsche [1908] 2005, p. 123).

The massiveness and silent solidity of the stone contrasts with everything that is imagined or designed to embody lightness and transience; (so elusive are sounds of music). However, the feeling of gravity (and of graveness) is unfamiliar to Nietzschean Zarathustra, a deity of ecstatic dance and music (the Dionysian element). In Nietzsche, "the spirit of gravitation"—as says the title of a chapter included in the third part of the book-has been associated with the shackles of conscience. Ewig wechselnd, as the idea that, in a way, evokes the vision of an "empty Hell", may induce, or at least inspire a human being to travel "beyond good and evil".

It is worth remarking that Nietzsche inherited the concept of "eternal alteration" from a great poet, Johann Wolfgang von Goethe. Precisely speaking, the expression "ewig wechselnd" appears in the Goethean Song of the Spirits over the Waters (Gesang der Geister über den Wassern; see: von Goethe [1779] 1827, p. 58). That is probably why von Trier's Vergil is wearing a black frock coat, not the traditional mantle, even if it rather represents a style distinctive of late 19th century fashion. Perhaps that is why Bruno Ganz, while interpreting Verge's character, did not attempt to conceal his natural German accent (though with some Swiss inflections).

Besides which, von Trier alludes to the great pre-Romantic poet in a clear and explicit way by employing the motif of Goethe's oak - the famous tree that, in the darkest times, was surrounded by barbed wires of the Buchenwald concentration camp, until destroyed by a bomb in 1944. That stately 
old oak may be seen as a symbol of poetic tradition and of lyrical beauty: the beauty that is lost. The act of putting that natural "icon" in the parentheses of the murderous architecture signified an irreparable, ultimate rupture, that is, a rupture with the great tradition, and, also perhaps, with the hope for apokatastasis. "As you can see, there was a bridge. However, that was before my time" —says Verge in the last sequence of the film.

I think it is no exaggeration to say that Romantic literature (and art) represents an intermediate stage in the evolution between the regular, ordered beauty of "classic" tradition (in the broadest sense of the word "classic") and, as André Breton put it, "convulsive", transgressive beauty enunciated by modernists, to whom breaking the conventional rules became an aesthetic necessity. However, before I move on to discussing Bataille's concept of the sacred transgression (or even sacred villain), let me for a moment go back to Dante's magnum opus.

William Franke, in an interesting publication entitled Dante and the Sense of Transgression, goes so far as to define the Divine Comedy as specifically a "self-dismantling" oeuvre" (Franke 2013, p. xxii). On the one hand, admittedly, the great Florentine appears to the reader as a eulogist of the divine order, a righteous man, and even a ruthless moralist. On the other hand, though, the language in which $\mathrm{La}$ Divina Commedia was written itself-experimental for its time-makes him a transgressionist. For, as Franke remarks, in his analyses referring to psychoanalytic terminology: “Dante's very obsession with avoiding and repressing transgression betrays an unmistakable sense of his own deeply and ineradicably transgressive desires" (ibid., p. 4). In Franke's view, a proof of Dante's hidden, one could say unconscious pursuit to transcend taboo, lies also in his specific reverence for the figure of mythical Marsyas (Paradiso, canto I.), who dared to compete with the Olympian god of light-Apollo: a veritable hubris (That Greek term is used several times in von Trier's film). As the author concludes: "Of the figures from the repertoire of Ovidian victims of gods' vengeance against human artists who dared to rival them, it is the satyr Marsyas who is most tellingly compared to Dante himself" (ibid., p. 7).

In the further course of his argument, Franke draws an analogy between Dantean oltraggio ("beyondness") and "Bataille's eye turned upwards and turned against itself (l'oeil révulsé)" (ibid., p. 137). (It is worth noting that, in a way, a similar Bataillean motif of an "eye" has been used in the typography of posters designed for von Trier's Nymphomaniac of 2013). As the scholar indicates, it is the reading of the philosophers of difference-Bataille, Foucault or Deleuze, to name just a few-that "could be used to elucidate, in terms addressed to our own time and intellectual horizon, the nature of poetic language as theological revelation in the final movement of Dante's epic and prophetic poem" (ibid., p. x). Then, let me now turn to Bataille's heterology (hétérologie), whose intellectual heritage is, in my opinion, strongly reflected in von Trier's films.

\section{Bataille's “Upturned Eye"—Reconciling Eros and Thanatos}

The market value of suffering and death had become superior to that of pleasure and sex, Jed thought, and it was probably for this reason that Damien Hirst had, a few years earlier, replaced Jeff Koons at the top of the art market.

(Michel Houellebecq, The Map and the Territory; Houellebecq [2010] 2011, pp. 251-52)

Beauty will be convulsive, or will not be at all.

(André Breton, Nadja; Breton [1928] 1960, p. 160)

Michel Houellebecq, in his brilliant novel La carte et le territoire (awarded the Prix Goncourt in 2010), creates a portrayal of postmodern culture as being in a state of regression, retreating back to its "oral phase", and, and the same time, experiencing a profound fascination with crime and death. The protagonist of the book, a painter named Jed Martin, endeavours to create a painting that would depict an imaginary scene of Damien Hirst and Jeff Koons Dividing up the Art Market. One could assume that Martin's (never-completed) allegorical composition reproduces the motif of the struggle 
between Eros (the pink, vivid shine of the American) and Thanatos (the disturbing black humour of the Englishman).

Yet, despite Houellebecq's anticipations, the art world of today seems to draw from both sources in almost similar measure as witnessed by the fact that it was Koons's work that broke the price record at Christie's NY auction. His steel Rabbit of 1986, now labelled as "the most expensive work by a living artist", was sold for 91.1 million dollars in May 2019. It is most probably because Eros and Thanatos are, in fact, complementary forces, elements of equal significance to the strategy of artistic transgression-the transgression that has already been, in a paradoxical way, institutionalised, and that takes its inspirations mostly (even if not always consciously) from Bataille's writings.

The theme of taboos, and of the blissful necessity of transgressing them, was of particular interest to Lord Auch ${ }^{20}$ in his essayistic study on L'Érotisme (1957), which was to a large extent influenced by Marquis de Sade's writings; see (Bataille [1930] 1986b, pp. 91-104). In the introductory part of the book, Bataille reflects upon the human condition-that is, our subjectivity (and individuality), which is transitory and governed by chance-as well as, a contrario, upon our obsessive yearning for a lost, primordial "continuity". ${ }^{21}$ Although discontinuity is a principle in the chain of procreation, it is eroticism-involved in the "alliance" with death—that abolishes our transient subjectivity and the temporality of our existence. "Eroticism is assenting to life even in death"—as Bataille writes in the introduction to his grand oeuvre (Bataille [1957] 1986, p. 11). La petit morte-the post-orgasmic "little death" suspends, at least for a moment, the appearance of an individual's particular "Self". The disinterested pleasure, freed from reproductive goals, brings one back to the continuum of all being, to the flux in which everything is connected. In this sense, one might regard an erotic act as an act of transgressive communication. According to Bataille, the same applies to crime. As he states in his book On Nietzsche: "All 'communication' participates in suicide, in crime ... By destroying the integrity of existence in myself and in others, I open myself to communion-I attain a moral summit. And the summit isn't a submission to but a willing of evil" (Bataille [1945] 1994, p. 26).

This "moral summit", however, must not be confused with the "summit of knowledge". ${ }^{22}$ Each human—as a "discontinuous creature" yearning for continuity (Bataille [1957] 1986, p. 129)—is, actually, left alone in a shady void. The "constitution of being" is "labyrinthian", says Bataille in L'expérience intérieure (Bataille [1943] 1988, p. 84). ${ }^{23}$

Each of the three types of eroticism distinguished by Bataille-l'érotisme des corps (body), l'érotisme des couurs (heart) and l'érotisme sacré (the sacred one)—as a kind of "inner experience" (Bataille [1957] 1986, p. 29), is accompanied by a sense of existential dread, as well as, again: by the uncanny play of repulsion and attraction. ("Unless the taboo is observed with fear it lacks the counterpoise of desire which gives it its deepest significance"; (ibid., p. 37)).

One may state that, in a metaphorical way, an erotic (transgressive) act entails a temporary disintegration or, at least, a fracture in the architecture of an individual being. In this context, the notion of "formless" (l'informe)—as conceptualised by Bataille for the first time in his article of 1929, issued by "Documents" - appears to be especially significant. (In the same year, "Documents" magazine also featured his short essay on Architecture, to which I will return below). Nevertheless, l'informe, to use Bataillean terminology-like "spit" (crachat), or a smashed insect, is antithetical for the reality

20 One of Bataille's indecent pseudonyms.

21 It is the continuity that would end "our discontinuous mode of existence as defined and separate individuals" (Bataille [1957] 1986, p. 18).

22 "This flight headed towards the summit (which is the constitution of knowledge-dominating the realms themselves) is only one of the paths of the 'labyrinth'. However we can now in no way avoid this path which we must follow from attraction to attraction in search of 'being'" (Bataille [1943] 1988, p. 86).

23 " [... A Around me extends the void, the darkness of the real world-I exist, I remain blind, in anguish ( ... ) If I envisage my coming into the world (... ) a single chance decided the possibility of this self which I am" (Bataille [1943] 1988, p. 69). In the same passage, dedicated to death—as, "in a sense, an imposture" — we read: "It is by dying, without possible evasion, that I will perceive the rupture which constitutes my nature and in which I have transcended "what exists" (...). The self-that-dies (...) truly perceives what surrounds it to be a void and itself to be a challenge to this void..." (ibid., p. 71). 
which is well-described, well-ordered, precisely classified and donned with a mathematical frock coat" (Bataille [1929] 1986, p. 31). ${ }^{24}$ "Formless" is thus an antithesis for each oppressive system, and also for architecture itself; and that is because in all totalitarianism, architecture serves as a visual manifestation of its "ideals".

In perhaps the most interesting chapter of the Erotism, entitled Transgression, Bataille discusses, in a more detailed way, the amphibolic character of taboo. There, he points out that an object of social prohibition —inviolable and "untouchable" — may become, at the same time, an object of the most intense desire - the one that provokes the most seditious or blasphemous deeds, obviously being taken up not in times of work and collecting goods, but in moments of extraordinary derangements or exaltations. Hence, as the philosopher says: "The profane world is the world of taboos. The sacred world depends on limited acts of transgression. It is the world of celebrations, sovereign rulers and God" (Bataille [1957] 1986, pp. 67-68).

Most importantly, however, those "limited acts" of rule-breaking never destroy the existing order as it is, quite the contrary: they serve to maintain, or even petrify the status quo. As Bataille concludes: "The transgression does not deny the taboo but transcends it and completes it" (Bataille [1957] 1986, p. 63). ${ }^{25}$ Too radical a transgression, exhausting itself in the very act of negation and excluding the possibility of a retreat to "normal" state may, as a matter of fact, turn into a devastating revolution, a diabolic terror. Of such character are the deeds committed by von Trier's protagonist, Jack.

The diabolic terror of nazi-fascism is metaphorically depicted in the last film by Pier Paolo Pasolini: Salò o le 120 giornate di Sodoma (1975), inspired by de Sade's Les cent vingt journées de Sodome ou l'école du libertinage - the novel written in the dungeons of the Bastille, and unpublished until $1904 .^{26}$ Moreover, the composition of Pasolini's famous work is divided into Anteinferno and three subsequent sections (Circles), which is an obvious reference to Dantean vision of hell. Thus, it is highly possible that The House that Jack Built in an immediate way draws from the darkest fantasy of the renowned Italian director.

The spatial metaphors in Bataille's oeuvre have been discussed by Denis Hollier in his book suggestively entitled Against Architecture (the original text had been published in French as La prise de la Concorde, 1974). Hollier considers Bataille's thought as a precursor to poststructuralism as he remarks that the philosopher "died even before people started to talk about structuralism". "There is a desire" - says Hollier-" to loosen the symbolic authority of architectures in poststructuralism, and in retrospect it is possible to see Bataille as the precursor of this critical view of architecture" (Hollier [1974] 1989, p. 9).27

24 A dictionary begins when it no longer gives the meaning of words, but their tasks. Thus formless is not only an adjective having a given meaning, but a term that serves to bring things down in the world, generally requiring that each thing have its form. What it designates has no rights in any sense and gets itself squashed everywhere, like a spider or an earthworm. In fact, for academic men to be happy, the universe would have to have shape. All of philosophy has no other goal: it is a matter of giving a frock coat to what is, a mathematical frock coat. On the other hand, affirming that the universe resembles nothing and is only formless amounts to saying that the universe is something like a spider or spit (Bataille [1929] 1986, p. 31).

25 Later in the text, Bataille writes: "Transgression is complementary to the profane world, exceeding the limits but not destroying it" (Bataille [1957] 1986, p. 67). A similar thought may be found in Chris Jenks: "To transgress is to go beyond the bounds or limits set by a commandment or law or convention, it is to violate or infringe. However to transgress is also more than this, it is to announce or even laudate the commandment, the law or the convention. Transgression is deeply reflexive act of denial and affirmation" (Jenks 2003, p. 3).

26 Philippe Roger describes de Sade as "a political minimalist", stating that it is inappropriate to link his oeuvre (solely) with "the excess of evil". As he remarks: "[ ... ] While his contemporaries use fiction as a transparent veil and a coded convention to convey and promote ideas, Sade 'fictionalizes' ideology to stir, displace, shock. Ambiguity prevails in all of his political declarations" (Roger 1995, p. 80). And further we read: "[ ... ] Cruelty is not violence, and even less it is politically motivated or state-sponsored violence" (ibid., p. 82).

27 Chris Jenks, in the aforementioned study on Transgression points out the importance of, as he says: "Kojève's intervention"; that is, to the profound impact that the Russian-French philosopher had on the poststructuralist movement. Among those who attended Alexandre Kojève's Sorbonne lectures (1933-1939)—dedicated mostly to the Hegelian Phenomenology of Spirit-was Bataille, as well as, for example: André Breton, Raymond Queneau, and Jacques Lacan (Jenks 2003, p. 61). 
The idea of the scared character of transgression—as of every blasphemy-fully developed on the pages of L'Érotisme, had been introduced almost thirty years earlier in the above-mentioned essay on Architecture (Bataille 1929, pp. 171-72)—short but rich in content. There, Bataille writes, exposing the oppressiveness of structural forms: "Architecture is the expression of every society's very being ... [But] only the ideal being of society, the one that issues orders and interdictions with authority, is expressed in architectural compositions in the strict sense of the word" (see: Hollier [1974] 1989, p. ix). Therefore, buildings and edifices symbolise the relations of social power: they are "real masters" in the iconosphere of their time (and their users). ${ }^{28}$ Then, architecture may be understood as, to quote Hollier, "a society's authorised superego", or, as an ostentatiously open, spectacular prison: quite different from Foucault's panopticon, which is "an architecture that sees, observes, and spies ... " (ibid., pp. ix-x).

Later in the text, Bataille makes an interesting symbolic juxtaposition between the museum (Musée) and the slaughterhouse (Abattoir). Here again we are dealing with the complementary forces of Eros (the desire for beauty) and Thanatos (the cruelty of death). As Hollier poetically remarks: "Within the heart of one the other is hidden. At the heart of beauty lies a murder, a sacrifice, a killing ... " (Hollier [1974] 1989, p. viii) (those contradictory, but inextricably bound elements-creation and destruction-participate in the economy and, more so, the metabolism of social "expenditure" (dépense) which will be the key notion in Bataille's study of 1949: La part maudite).

Against all appearances, it is not museums-being, in fact, relics left after the dark age of Terror ${ }^{29}$ - but slaughterhouses of La Villette that, in Bataille's "upturned eye", take on a sacred, even a "religious" character. That is because l'abbatoir is a place where the eternal sacrificial ritual is celebrated:

"The slaughterhouse relates to religion in the sense that temples of times past ... had two purposes, serving simultaneously for prayers and for slaughter ... Nowadays, the slaughterhouse is cursed and quarantined like a boat with cholera abroad ... The victims of this curse are neither butcher nor the animals, but those fine folks who have reached the point of not being able to stand their own unseemliness, an unseemliness corresponding in fact to a pathological need for cleanliness" (Hollier [1974] 1989, pp. 12-13).

To Bataille, the architecture of the human body, with its outwardly limited form, seems hellish: "Man's revolt against prison is a rebellion against his own form, against the human figure", says Hollier ([1974] 1989, p. ix). Only by way of transgression may one experience the feeling of the blissful "formlessness". Here, the wings of Icarus-the son of Daidalos, who built the Cretan Labyrinth—that melt in Bataillean "rotten sun" (Soleil pourri), serve as the best metaphoric parallel (see: Bataille [1930] 1986a, p. 58).

Transgressing (deconstructing) the social order-as Bataille reckons—does not mean "going back to nature". To him, nature is rather a kind of a profane Hell: and it is responsible for human "discontinuity". "Nature is the satan's church"—-says she (Charlotte Gainsbourg) in the already mentioned von Trier's Antichrist. However, at the same time, it is nature that-as Jack the murderer points out-inspires art with its (cruel) methods. Wine, as a symbol of dry extravagance and excess is yet a kind of l'art pour l'art. Jack says:

"In order to achieve the most sublime sweetness and the greatest wines, nature has provided us with various methods. The three most common forms of decomposition are frost ... dehydration ... and a fungus with the enticingly mysterious name, the noble rot".

The above-quoted words might as well be a poetic illustration to the Freudian notion of "sublimation" - one of the ego defence mechanisms that is, to a large extent, responsible for artistic

28 "The storming of the Bastille is symbolic of this state of affairs: it is hard to explain this mass movement other than through the people's animosity (animus) against the monuments that are its real masters." See: (Hollier [1974] 1989, pp. ix-x).

29 "The museum is what the Terror invented to replace the king, to replace the irreplacible". See: (Hollier [1974] 1989, p. xiii). In the same place Bataille writes: "The origin of the modern museum would thus be linked to the development of the guillotine." See: (ibid., p. xiii). 
creativity. (In his Totem and Taboo of 1913, Freud identifies the common source of creative drives and obsessive-compulsive disorder, which is, in his view, the animistic faith in the "omnipotence of thought". As I have mentioned at the beginning, it is striking that Jack, the psychopath, suffers from OCD).

All in all, mortal, perishable bodies of discontinuous beings (Bataille) may inspire the greatest and most sophisticated forms of art. As von Trier's protagonist remarks: "The soul belongs to heaven, and the body to hell. The soul is reason and the body is all the dangerous things, for example art and icons". It is actually a strong echo of Bataille's statement:

"Nature herself is violent, and however reasonable we may grow, we may be mastered anew by a violence no longer that of nature but that of a rational being who tries to obey but succumbs to stirrings within himself which he cannot bring to heel" (Hollier [1974] 1989, p. 40).

\section{Great Edifices and Miserable Ruins}

Mattias Frey in his study entitled Extreme Cinema: The Transgressive Rhetoric of Today's Art Film Culture, analyses the social status-one might say the habitus ${ }^{30}$ - of iconoclastic works located in the domain of "high arts" (and "art cinema), including those of von Trier. The House that Jack Built-even if, for obvious reasons, it could not have been discussed in the book (published in 2016) —would perfectly fit in the definition of "extreme cinema" as proposed by Frey. Let me add the definition that has a sociological undertone:
"Speaking roughly and simply, extreme cinema is an international production trend of graphically sexual or violent 'quality' films that often stoke critical and popular controversy. Indeed, the trend is distinctive insofar as institutional incentives anticipate a controversial response. Premiering at glamorous film festivals among cultural sophisticates, playing at upmarket cinemas, and featuring in the 'world cinema', 'independent', or 'arthouse' sections at video stores and online streaming services, these productions depend on (offering) culturally inscribed boundaries between art and exploitation." (Frey 2016, p. 7).

One could say that such cinematic productions partake in a kind of ritual, that is - the social ritual of scandal. (For, it is the skandalon, the "stone of stumbling", of disgust, that is so much expected by the viewer, whoever wants to be confirmed in his/her "just" indignation). Indeed, it is difficult to dispute Frey's conclusion that von Trier deliberately plays with his viewers' expectations, and that he retains his "carefully cultivated reputation" — an echo of Howard Becker's theory of reputation is present here-_"as eccentric, exotic, volatile, or as 'particularly difficult' to work with" (Frey 2016, p. 20). Von Trier's "rebellious, artistic habitus" (ibid., p. 24), has been ultimately affirmed by his controversial statement at the Cannes conference, and then, by his wearing a t-shirt emblazoned with the phrase 'persona non grata' at the Berlinale 2014. His latest provocative statements do not really contribute much to that, metaphorically speaking, well-varnished canvas. Even when, in an interview for the "Irish Times", he comments on the public's reaction at the premiere of The House that Jack Built, in such a way: "That is fine with me ... It is important that a film divides. I am disappointed that it was only 100 people that vomited. I would have liked 200 people to vomit" (see: Clarke 2018).

That "rebellious habitus" has its origins as far back as in the Romantic period: to be more precise, in the romantic myth, 31 elevating an artist-as a genius—to heights far above the mundane crowd. Moreover, it has been reinforced by the Nietzschean vision of the Overman (Übermensch), unfamiliar

30 The notion of habitus used here is closely connected to the one conceptualised and described by Pierre Bourdieu in $L a$ Distinction. Critique sociale du judgement (Paris: Minuit, 1979), or in Le Sens pratique (Paris: Seuil, 1980).

31 As Howard Becker writes, in his already classic study on Art Worlds, first published in 1982: "The romantic myth of the artist suggests that people with such gifts cannot be subjected to the constraints imposed on other members of society; we must allow them to violate rules of decorum, propriety, and common sense everyone else must follow on risk of being punished." See: (Frey 2016, p. 14). 
with the "gravity" of consciousness, and—as I proved above—by the Bataillean apotheosis of the sacred transgression.

From that standpoint, let me say it once more-von Trier's last oeuvre is, indeed, by all means "traditional". Furthermore it is the immersion in tradition, followed by metaphoricalness, allusiveness, and von Trier's deep cultural erudition-though sometimes masked with trivial statements-that makes his films finely structured "edifices".

Then, what about the house that Jack has built? Well, there is one last reference to architecture in the film, which I have deliberately left to the end, that is Abert Speer's "theory of ruin value" (Ruinenwerttheorie): a specific counterpoint to the above-mentioned Goethe's oak. Speer's antimodern designs for Welthauptstadt Germania were calculated so as to outlast the "millennial Reich", though, in a state of "noble ruins", weathered by time- the ruins that would prompt associations with the greatest achievements of Greek-Roman antiquity. Fortunately, "the capital of the world" has been realised only in a very small part. And yet, it is Heidegger's dull and simple hut that served as a prefiguration for Speer's neoclassical, dreary edifices. Miserable were the ruins of the Nazi state, and miserable the ruins of the philosophy that transformed into the criminal ideology.

Jack's house, horrifying and dangerously "useful", is, similarly to Speer's architecture, antimodern in its character, whereas the strategy employed by the Danish director is fully (post)modern, cleverly constructing his labyrinthian tale. A murderer, merely an "engineer" of crime, cannot be a brilliant architect: his hubris always needs to be punished by the goddess of divine retribution, Nemesis. At the same time, though, hubris is a condition sine qua non, under which one may become a conscious artist, an architect of metaphorical images.

Crime results only in the ultimate destruction, in the hell of non-being. (J: "Isn't it possible to climb all the way around (... ) and make it over to the other side? V: Quite a few have tried, but I have to say ... never successfully"), whilst artistic transgression is inscribed in the logic of "the eternal recurrence".

So, Mr. Sophistication turned out to be merely an artisan of vice and, like every predator, just an element of the natural world, subject to simplest natural laws, not "sophisticated" at all. The house that Jack built is merely die Hütte. The house that Lars built is a dark and beautiful masterpiece.

Funding: This research received no external funding.

Conflicts of Interest: The author declares no conflict of interest.

\section{References}

à Kempis, Thomas. 1998. The Different Motions of Nature and Grace. In Thomas à Kempis, The Imitation of Christ. Wheaton: Christian Classics Ethereal Library, pp. 90-92. First published [ca. 1400]. Available online: http://www.ccel.org/ccel/kempis/imitation.html (accessed on 17 June 2020).

Bataille, Georges. 1986. Formless. In Visions of Excess. Selected Writings, 1927-1939. Translated and Edited by Allan Stoekl. Minneapolis: University of Minnesota Press, pp. 31-43. First published 1929.

Bataille, Georges. 1986a. Rotten Sun. In Visions of Excess. Selected Writings, 1927-1939. Translated and Edited by Allan Stoekl. Minneapolis: University of Minnesota Press, pp. 57-58. First published 1930.

Bataille, Georges. 1986b. The Use of Value of D. A. F. Sade. An Open Letter to My Current Comrades. In Visions of Excess. Selected Writings, 1927-1939. Translated and Edited by Allan Stoekl. Minneapolis: University of Minnesota Press, pp. 91-104. First published 1930.

Bataille, Georges. 1986. Erotism: Death and Sensuality. Translated by Mary Dalwood. San Francisco: City Light Books. First published 1957.

Bataille, Georges. 1988. Inner Experience. Translated by Leslie A. Boldt. New York: State University of New York Press. First published 1943.

Bataille, Georges. 1994. On Nietzsche. Translated by Bruce Boone. New York: Paragon House. First published 1945. Bataille, Georges. 1929. Architecture. Documents: Doctrines, Archéologie, Beaux-Arts, Ethnographie 2: 117.

Bois, Yve-Alain, and Rosalind Krauss. 1997. Formless: A User's Guide. New York: Zone Books. 
Breton, André. 1960. Nadja. Translated by Richard Howard. New York: Grove Press, Paris: Gallimard. First published 1928.

Clarke, Donald. 2018. Lars Von Trier: 'I Am Disappointed only 100 People Vomited'. The Irish Times, December 7. Available online: https://www.irishtimes.com/culture/film/lars-von-trier-i-am-disappointed-only-100people-vomited-1.3719920(accessed on 16 June 2020).

Collinson, Paul. 2019. Heidegger's Hut. Dreaming of the Middle Ages, and the Absolute-A Visual Essay. Available online: https://www.academia.edu/38091838/Heideggers_Hut_Dreaming_of_the_Middle_Ages_ and_the_Absolute_a_visual_essay (accessed on 15 June 2020).

Durham, Scott. 1998. Phantom Communities. The Simulacrum and the Limits of Postmodernism. Stanford: Stanford University Press.

Dyer, Richard. 2007. Pastiche. New York and London: Routledge, Available online: http://www.columbia.edu/itc/ film/gaines/historiography/Dyer.pdf (accessed on 12 November 2020).

Franke, William. 2013. Dante and the Sense of Transgression: The Trespass of the Sign. London and New York: Bloomsbury Academic.

Freud, Sigmund. 1959. The Uncanny. In Collected Papers. Edited by Joan Riviere. Translated by Alix Strachey. New York: Basic Books, vol. 4, pp. 368-407. First published 1919.

Frey, Mattias. 2016. Extreme Cinema: The Transgressive Rhetoric of Today's Art Film Culture. New Brunswick and London: Rutgers University Press.

Fried, Gregory. 2014. The King Is Dead: Heidegger's ‘Black Notebooks'. Los Angeles Review of Books, September 13. Available online: https://lareviewofbooks.org/article/king-dead-heideggers-black-notebooks/(accessed on 14 June 2020).

Fried, Gregory, ed. 2019. Confronting Heidegger: A Critical Dialogue on Politics and Philosophy. London: Rowman and Littlefield Int.

Gilbey, Ryan. 2017. Lars von Trier Negotiating for Cannes Return after 2011 Nazi Comments Ban. The Guardian, March 9. Available online: https:/www.theguardian.com/film/2017/mar/09/lars-von-trier-cannes-returnnazi-comments-ban(accessed on 15 June 2020).

Halliwell, James O. 1842. The Nursery Rhymes of England, Collected Principally from Oral Tradition. London: The Percy Society, Available online: https://books.google.pl/books/about/The_Nursery_Rhymes_of_England_Collected. html?id=gs1swgEACAAJ\&redir_esc=y (accessed on 15 June 2020).

Halliwell, James O. 1849. Popular Rhymes and Nursery Tales: A Sequel to the Nursery Rhymes of England. London: John Russell Smith Ltd., Available online: https://archive.org/details/popularrhymesnur00hallrich/page/6 (accessed on 15 June 2020).

Hassan, Ihab. 1985. The Culture of Postmodernism. Theory, Culture Society 2: 119-32. [CrossRef]

Hassan, Ihab. 2003. Beyond Postmodernism: Towards an Aesthetic of Trust. Angelaki. Journal of the Theoretical Humanities 8: 3-11. Available online: https://www.tandfonline.com/doi/abs/10.1080/09697250301198 (accessed on 12 November 2020).

Hegel, Georg W. F. 1975. Architecture. In Aesthetics. Lectures on Fine Art. Translated and Edited by Thomas Malcolm Knox. Oxford: Oxford Univeristy Press and Clanderon Press, vol. 2, pp. 630-700. First published 1835.

Heidegger, Martin. 2013. Nature, History, State: 1933-1934. Translated and Edited by Gregory Fried, and Richard Polt. London and New York: Bloomsbury Academic. First published 1933-1934.

Hollier, Denis. 1989. Against Architecture: The Writings of Georges Bataille. Translated by Betsy Wing. Cambridge and London: The MIT Press. First published 1974.

Houellebecq, Michel. 2011. The Map and the Territory. Translated by Gavin Bowd. London: William Heinemann Ltd. and The Random House Group. First published 2010.

Jakobson, Roman. 2002. Two Aspects of Language and Two Types of Aphasic Disturbances. In Roman Jakobson and Morris Halle, Fundamentals of Language. Berlin and New York: Mouton de Gruyter, pp. 67-96. First published 1956.

Jenks, Chris. 2003. Transgression. London and New York: Routledge.

Jung, Carl G. 1967. The Relation between the Ego and the Unconscious. In Collected Works of C.G. Jung, Volume 7: Two Essays in Analytical Psychology. Translated and Edited by Gerhard Adler, and Richard F. C. Hull. Princeton: Princeton University Press, pp. 123-244. First published 1916. 
Jung, Carl G. 2014. Crime and the Soul. In The Collected Works of C.G. Jung: Complete Digital Edition, vol. 18: The Symbolic Life. Miscellaneous Writings. Edited by Herbert Read, Michael Fordham and Gerhard Adler. Translated by Richard F. C. Hull. Princeton: Princeton University Press, pp. 343-46. First published 1932.

Jung, Carl G. 1997. Five Chapters from 'Aion'. In Selected Writings. Introduction by Robert Coles. New York: Book-of-the-Month-Club, pp. 285-355. First published 1951.

Jung, Carl G. 1989. Memories, Dreams, Reflections. Edited by Aniela Jaffé. Translated by Richard, and Clara Winston. New York: Random House. First published 1962.

Laugier, Marc-Antoine. 1753. L'essai sur l'architecture. Paris: Chez Duchesne, Available online: https://gallica.bnf. fr/ark:/12148/bpt6k856908/f20.item.zoom\# (accessed on 12 November 2020).

Laugier, Marc-Antoine. 1755. An Essay on Architecture. London: T. Osborne and Shipton, Available online: https: //archive.org/stream/essayonarchitect00laugrich?ref=ol\#page/12/mode/2up (accessed on 12 November 2020).

Lentricchia, Frank, and Jody McAuliffe. 2003. Crimes of Art and Terror. Chicago and London: The University of Chicago Press.

Nietzsche, Friedrich. 2009. The Birth of Tragedy Out of the Spirit of Music. Translated by Ian Johnston Arlington. Virginia: Richer Resources Publications. First published 1872.

Nietzsche, Friedrich. 2005. Ecce Homo: How to Become What You Are. In The Anti-Christ, Ecce Homo, Twilight of the Idols, and Other Writings. Edited by Aaron Ridley and Judith Norman. Translated by Judith Norman. New York: Cambridge University Press, pp. 69-151. First published 1908.

Nietzsche, Friedrich. 1911. The Dawn of Day. Translated by John McFarland Kennedy. New York: The MacMillan Company, Available online: http://www.gutenberg.org/files/39955/39955-pdf.pdf (accessed on 15 June 2020).

Ozick, Cynthia. 1997. Dostoyevsky's Unabomber. The New Yorker, February 24-March 3. Available online: https://www.newyorker.com/magazine/1997/02/24/dostoyevskys-unabomber(accessed on 17 June 2020).

Panofsky, Erwin. 2018. Studies in Iconology: Humanistic Themes in the Art of the Renaissance. New York: Routledge. First published 1939.

Parkes, Graham. 2005. Introduction. In Friedrich Nietzsche, Thus Spoke Zarathustra: A Book for Everyone and for Nobody. Translated by Graham Parkes. Oxford and New York: Oxford University Press, pp. ix-xxxiii.

Pollio, Marcus Vitruvius. 1914. Vitruvius. Ten Books on Architecture [De Architectura]. Translated by Morris H. Morgan. Cambridge: Harvard University Press. First published 1465, 30-20 BC. Available online: https://archive.is/LflcC (accessed on 12 November 2020).

Porębski, Mieczysław. 1972. Obraz otaczający: Architektura. In Mieczysław Porębski, Ikonosfera [Iconosphere]. Warszawa: PIW, pp. 151-69.

Roger, Philippe. 1995. A Political Minimalist. In Sade and the Narrative of Transgression. Cambridge: Cambridge University Press, pp. 76-99.

Sharr, Adam. 2006. Heidegger's Hut. Cambridge: The MIT Press.

Sherman, Josepha. 2015. Storytelling: An Encyclopedia of Mythology and Folklore. London and New York: Routledge, vol. 1-3.

Shklovsky, Victor. 1965. Art as Technique. In Russian Formalist Criticism: Four Essays. Edited by Lee T. Lemon and Marion J. Reiss. Lincoln and London: University of Nebraska Press, pp. 3-24. First published 1917.

Spicer, Jack. 1998. The House that Jack Built: The Collected Lectures. Edited by Peter Gizzi. Middletown: Wesleyan University Press.

Telegraph Reporters. 2018. PETA Defends Lars von Trier's 'Realistic' Baby Duck Mutilation Scene. The Telegraph, May 18. Available online: https:/www.telegraph.co.uk/films/2018/05/18/peta-defends-lars-von-triersrealistic-baby-duck-mutilation/(accessed on 18 June 2020).

The Einstein Couple. 2018. The Einstein Couple's Facebook Site, an Entry of September 26. Available online: https://www.facebook.com/theeinsteincouple/ (accessed on 17 June 2020).

Lars von Trier, director. 2018. The House that Jack Built. The screenplay by Lars von Trier. Available online: https://subslikescript.com/movie/The_House_That_Jack_Built-4003440 (accessed on 15 June 2020).

Turner, Victor. 1991. The Ritual Process. Structure and Anti-Structure. New York: Cornell University Press and Ithaka. First published 1969.

von Goethe, Johann Wolfgang. 1827. Gesang der Geister über den Wassern. In Goethe's Werke. Stuttgart and Tübingen: J. G. Gotta, pp. 58-59. First published 1779.

Welchman, John C. 2009. Global Nets: Appropriation and Postmodernity. In Appropriation. Edited by David Evans. Cambridge: The MIT Press, London: Whitechapel Gallery, pp. 194-204. 
Publisher's Note: MDPI stays neutral with regard to jurisdictional claims in published maps and institutional affiliations.

(C) 2020 by the author. Licensee MDPI, Basel, Switzerland. This article is an open access article distributed under the terms and conditions of the Creative Commons Attribution (CC BY) license (http://creativecommons.org/licenses/by/4.0/). 